\title{
Pengaruh Jenis Media Tanam dan Lama Perendaman Benih dalam Air Hangat terhadap Bibit Pepaya (Carica papaya L.)
}

\author{
Maxsimus Ulu ${ }^{\mathrm{a}}$, Roberto I.C.O. Taolin' ${ }^{\mathrm{b}}$, Regina Seran ${ }^{\mathrm{c}}$ \\ ${ }^{a}$ Fakultas Pertanian, Universitas Timor, Kefamenanu, TTU - NTT, Indonesia, email: mexulu25@gmail.com \\ ${ }^{b}$ Fakultas Pertanian, Universitas Timor, Kefamenanu, TTU - NTT, Indonesia, email: ricotaolin@gmail.com \\ ${ }^{c}$ Fakultas Pertanian, Universitas Timor, Kefamenanu, TTU - NTT, Indonesia, email: serangina02@ gmail.com
}

\section{Article Info}

\section{Article history:}

Received 22 Mei 2019

Received in revised form 10 Agustus 2019 Accepted 16 September 2019

DOI:

https://doi.org/10.32938/sc.v4i02.693

Keywords:

Carica papaya $\mathrm{L}$

Jenis Media Tanam

Perendaman

\section{Abstrak}

Penelitian ini bertujuan untuk mengetahui pengaruh lama perendaman terhadap bibit Pepaya dan untuk menguji jenis pupuk kandang serta arang sekam terhadap pertumbuhan bibit Pepaya. Penelitian ini dilaksanakan pada bulan Juli-September 2018 di kebun percobaan Fakultas Pertanian, Universitas Timor, Kelurahan Sasi, Kecamatan Kota Kefamenanu, Kabupaten TTU, menggunakan Rancangan Acak Kelompok (RAK) dengan dua faktor yakni faktor pertama adalah lama perendaman benih dalam air hangat yang terdiri dari 3 (tiga) aras yakni 30 menit, 60 menit, 120 menit. Faktor yang kedua yakni yang terdiri dari 4 (empat) aras yakni kontrol tanah kosong, tanah + arang sekam, tanah + pupuk kandang, tanah + arang sekam + pupuk kandang sapi. Semua kombinasi perlakuan diulang 3 kali sehingga seluruhnya terdapat 36 petak percobaan. Hasil penelitian menunjukkan bahwa tanaman Pepaya yang direndam didalam air hangat selama 120 menit dan diberikan perlakuan media tanam tanah + arang sekam + pupuk kandang sapi dapat meningkatkan pertumbuhan tanaman Pepaya yang dapat diekspresikan dalam bentuk tinggi tanaman tertinggi, jumlah daun terbanyak dan diameter terbesar.

\section{Pendahuluan}

Pepaya (Carica papaya L.) merupakan salah satu jenis tanaman buahbuahan yang daerah penyebarannya berada di daerah tropis. Buah Pepaya tergolong buah populer dan umumnya digemari oleh sebagian besar penduduk dunia. Hal ini disebabkan karena daging buahnya yang lunak dengan warna merah atau kuning, rasanya manis dan menyegarkan serta banyak mengandung air. Tanaman Pepaya merupakan tanaman tahunan sehingga buah ini dapat tersedia setiap saat (Barus, 2008). Pepaya merupakan buah yang mempunyai nilai nutrisi, dapat dimanfaatkan dalam bentuk buah segar dan produk hasil olahan. Pepaya mengandung banyak vitamin, dapat dijadikan olahan sayur baik daun, bunga, maupun buahnya (Sankat dan Maharaj, 1997). Buah Pepaya yang telah matang secara fisiologi menghasilkan biji didalam daging buah, serta biji buah Pepaya akan tumbuh setelah melewati masa penyimpanan yang disebut sebagai benih. Benih Pepaya termasuk benih ortodoks tetapi memeliki waktu penyimpanan yang relative singkat (Nurngaini et al., 2017) sehingga perlu cara untuk mematahkan sifat dormansi pada benih. Salah satu cara adalah dengan merendam benih dalam air panas pada suhu tertentu dengan waktu tertentu. Lisarini dan Suwand (2011) menyatakan bahwa benih Pepaya yang direndam dalam air panas dengan suhu $50^{\circ}$ dan $75^{\circ}$ selama 1 hari menghasilkan keserempakan perkecambahan lebih baik dan lebih cepat 1 sampai dua hari. Selain itu untuk mendapatkan pertumbuhan awal Pepaya yang baik diperlukan pemupukan.

Pemupukan merupakan salah satu usaha yang harus dilakukan untuk mencapai tingkat produksi tanaman yang tinggi dengan kualitas yang baik. Pemupukan juga merupakan suatu tindakan pemberian unsur hara pada tanaman, baik pada tempat tumbuh atau pada bagian tanaman dengan maksud untuk mendapatkan pertumbuhan yang normal dan subur sehingga mampu memberikan pertumbuhan yang baik dan dapat berproduksi dengan baik. Pupuk kandang merupakan salah satu pupuk organik yang memiliki beberapa fungsi penting (Sutedjo, 1987). Pupuk kandang adalah salah satu pupuk organik yang memiliki kandungan hara yang dapat mendukung kesuburan tanah dan pertumbuhan mikroganisme dalam tanah. Pemberian pupuk kandang selain dapat menambah tersedianya unsur hara yang dapat mendukung pertumbuhan mikro organisme serta memperbaiki struktur tanah (Mayadewi, 2007). Pupuk kandang memiiki sifat alami dan tidak merusak tanah. Pupuk kandang menyediakan unsur hara makro seperti Nitrogen, Fosfor, Kalium dan Kalsium serta unsur hara mikro seperti Besi, Seng, Boron, Kobalt, dan Molibdenium. Mayadewi (2007); Nasahi (2010) menyatakan bahwa penggunaan pupuk kimia atau organik dapat menyebabkan penipisan unsur-unsur mikro seperti Seng, Besi, Tembaga, Mangan, Magnesium, dan Boron yang bisa mempengaruhi pertumbuhan tanaman, hewan dan kesehatan manusia.

Arang sekam memiliki kemampuan menyerap air yang rendah dan porositas yang baik. Sifat ini menguntungkan jika digunakan sebagai media tanam karena mendukung perbaikan struktur tanah karena aerasi dan drainase menjadi lebih baik. Menurut Isro'i (2008) bahwa pada media tanam sekam kompos banyak membawa keuntungan yaitu mengandung Karbon (C) yang membuat media tanam menjadi gembur. Hal ini membantu merangsang pertumbuhan secara keseluruhan khususnya batang, cabang, dan daun serta zat hijau daun untuk fotosintesis dan memiliki unsur Fosfor dan Calium yang dibutuhkan tanaman dibandingkan dengan pupuk kandang.

Kondisi media tanam yang baik sebagai akibat pengaruh dari kompos mendorong perakaran tanaman tumbuh secara optimal dengan demikian akan meningkatkan ketersediaan unsur Nitrogen, Fosfor, dan Kalium. Dari uraian tersebut maka penelitian ini bertujuan untuk mendapatkan lama perendaman benih Pepaya dalam air hangat dan media tanaman yang tepat untuk pertumbuhan awal Pepaya.

\section{Metode}

Penelitian ini dilaksanakan pada bulan Juli-September 2018 di kebun percobaan Fakultas Pertanian Universitas Timor, Kelurahan Sasi Kecamatan Kota Kefamenanu Kabupaten TTU. Peralatan yang digunakan dalam penelitian ini yaitu linggis, ember, penggaris, gembor, alat ukur jangka sorong, dan alat tulis menulis. Bahan-bahan yang digunakan dalam penelitian yakni benih Pepaya California yang diperoleh dari toko pertanian dan pupuk kandang sapi, arang sekam, polybag dan tanah. Penelitian ini menggunakan Rancangan Acak Kelompok (RAK) faktorial. Faktor pertama lama perendaman benih dalam air hangat $(\mathrm{P})$ yang terdiri atas 3 aras yaitu: lama perendaman 30 menit $\left(\mathrm{P}_{1}\right)$, lama perendaman 60 menit $\left(\mathrm{P}_{2}\right)$, lama perendaman 120 menit $\left(\mathrm{P}_{3}\right)$. Faktor kedua adalah jenis media tanam (L) yang terdiri dari 4 aras yaitu: kontrol tanah kosong $\left(\mathrm{L}_{0}\right)$, tanah + arang sekam $\left(\mathrm{L}_{1}\right)$, tanah + pupuk kandang sapi $\left(\mathrm{L}_{2}\right)$, tanah + arang sekam + pupuk kandang sapi $\left(\mathrm{L}_{3}\right)$. Kombinasi perlakuan adalah: $\mathrm{P}_{3} \mathrm{~L}_{2}$, $\mathrm{P}_{1} \mathrm{~L}_{3}, \mathrm{P}_{3} \mathrm{~L}_{3}, \mathrm{P}_{3} \mathrm{~L}_{1}, \mathrm{P}_{1} \mathrm{~L}_{2}, \mathrm{P}_{0} \mathrm{~L}_{1}, \mathrm{P}_{2} \mathrm{~L}_{1}, \mathrm{P}_{0} \mathrm{~L}_{2}, \mathrm{P}_{0} \mathrm{~L}_{3}, \mathrm{P}_{1} \mathrm{~L}_{1}, \mathrm{P}_{2} \mathrm{~L}_{3}, \mathrm{P}_{2} \mathrm{~L}_{2}$ yang diulang 3 kali, sehingga seluruhnya terdapat 36 petak penelitian. Data-data yang diperoleh dari hasil pengamatan selanjutnya dianalisis dengan menggunakan sidik ragam (anova) RAK faktorial pada tingkat signifikan $5 \%$ dan untuk mengetahui ada tidaknya beda rata-rata antara perlakuan diuji dengan Duncan pada tingkat signifikan $5 \%$, sesuai petunjuk Gomez dan Gomez (2010). Analisis data menggunakan program SAS 9,1.

\section{Tinggi Tanaman $(\mathbf{c m})$}

Pengukuran tinggi tanaman dilakukan dengan menggunakan penggaris berskala $100 \mathrm{~cm}$. Pengukuran dilakukan setiap 2 minggu sekali mulai tanaman berumur 14 HST hingga tanaman berumur 56 HST. Pengukuran mulai dari leher akar sampai perpanjangan daun tertinggi.

\section{Jumlah daun}

Jumlah daun dihitung dengan cara menghitung semua tanaman. Jumlah daun dihitung setiap 2 minggu mulai umur 14 HST sampai umur 56 HST.

\section{Diameter batang}

Diameter batang diukur dengan cara menggunakan jangka sorong setiap 2 minggu mulai umur 14 HST sampai tanaman berumur 56 HST.

\section{Hasil dan Pembahasan \\ 3.1 Hasil Tinggi Tanaman}

Hasil sidik ragam (anova) menunjukkan bahwa tidak terjadi interaksi antara komposisi media tanam dan lama perendaman terhadap tinggi tanaman Pepaya. Hasil uji lanjut terhadap rerata perlakuan menunjukkan bahwa tidak terjadi beda nyata antara aras perlakuan pada semua waktu pengamatan namun pada waktu pengamatan 56 HST terjadi beda nyata dengan lama perendaman 120 menit menghasilkan tinggi tanaman tertinggi. Sedangkan pada aras perlakuan media tanaman tidak terjadi beda nyata pada awal pengamatan namun pada waktu pengamatan 24 HST sampai akhir mengamatan terjadi beda nyata antara aras perlakuan dengan aras perlakuan pemberian tanah + arang sekam + pupuk kandang sapi menghasilkan tinggi tanaman lebih tinggi (Tabel 1).

\section{Jumlah Daun}

Hasil sidik ragam (anova) menunjukkan bahwa tidak terjadi interaksi antara komposisi pupuk dan lama perendaman terhadap jumlah daun tanaman Pepaya. Aras perlakuan lama perendaman menunjukkan bahwa tidak terjadi beda nyata pada semua waktu pengamatan. Aras perlakuan media tanaman menunjukkan bahwa pada awal mengamatan menunjukkan tidak terjadi beda nyata antar aras perlakuan tetapi pada saat pengamatan 28 HST sampai dengan 
akhir pengamatan menunjukkan beda nyata denga naras perlakuan tanah + arang sekam + pupuk kandang sapi menghasilkan daun terbanyak (Tabel. 2).

Tabel 1. Tinggi Tanaman $(\mathrm{Cm})$

\begin{tabular}{|c|c|c|c|c|c|}
\hline \multirow{2}{*}{$\begin{array}{c}\text { Waktu } \\
\text { Pengamatan } \\
\text { (HST) }\end{array}$} & \multirow[b]{2}{*}{ Komposisi Pupuk } & \multicolumn{3}{|c|}{ Lama Perendaman (Menit) } & \multirow[b]{2}{*}{ Rerata } \\
\hline & & L1 (30) & L2 (60) & L3 (120) & \\
\hline \multirow{5}{*}{14} & Kontrol (P0) & 7.90 & 8.23 & 9.33 & $8.49^{\mathrm{a}}$ \\
\hline & Tanah+Arang Sekam (P1) & 8.97 & 8.07 & 9.40 & $8.81^{\mathrm{a}}$ \\
\hline & Tanah+ K. Sapi (P2) & 8.93 & 9.93 & 10.20 & $9.69^{\mathrm{a}}$ \\
\hline & Tanah+Sekal & 9.27 & 10.73 & 9.43 & $9.81^{\mathrm{a}}$ \\
\hline & Rerata & $8.77^{\mathrm{a}}$ & $9.24^{\mathrm{a}}$ & $9.59^{\mathrm{a}}$ & $(-)$ \\
\hline \multirow{5}{*}{28} & Kontrol (P0) & 8.33 & 9.43 & 9.87 & $9.21 \mathrm{c}$ \\
\hline & Tana & 10.33 & 9.73 & 10.67 & $10.24 \mathrm{bc}$ \\
\hline & Tanah+ K. Sapi (P2) & 10.80 & 10.63 & 11.83 & $11.09^{\mathrm{ab}}$ \\
\hline & Tanah+Sekam+K.Sapi (P3) & 11.37 & 12.93 & 11.33 & $11.88^{\mathrm{a}}$ \\
\hline & Rerata & $10.21^{\mathrm{a}}$ & $10.68^{\mathrm{a}}$ & $10.93^{\mathrm{a}}$ & $(-)$ \\
\hline \multirow{5}{*}{42} & Kontrol (P0) & 8.53 & 9.57 & 10.33 & $9.48^{\mathrm{c}}$ \\
\hline & Tana & 11.00 & 10.87 & 11.60 & $11.16^{\mathrm{b}}$ \\
\hline & Tana & 12.23 & 12.50 & 13.60 & 12.78 \\
\hline & Tanah & 12.93 & 15.07 & 13.33 & 13.78 \\
\hline & Rerata & $11.18^{\mathrm{a}}$ & $12.00^{\mathrm{a}}$ & $12.22^{\mathrm{a}}$ & $(-)$ \\
\hline \multirow{5}{*}{56} & Kontrol (P0) & 8.93 & 10.07 & 10.63 & 9.88 \\
\hline & Tanah & 12.50 & 13.13 & 13.97 & 13.20 \\
\hline & & 15.33 & 14.17 & 16.17 & 15.22 \\
\hline & Sapi (P3) & 15.33 & 17.33 & 17.83 & 16.83 \\
\hline & Rerata & $13.03^{\mathrm{b}}$ & $13.68^{\mathrm{ab}}$ & $14.65^{\mathrm{a}}$ & $(-)$ \\
\hline
\end{tabular}

Keterangan: Angka pada baris dan kolom diikuti huruf yang sama menunjukkan beda pada tingkat nyata 5\% menurut uji DMRT. (-) tidak terjadi interaksi antar faktor

Tabel 2. Jumlah Daun

\begin{tabular}{|c|c|c|c|c|c|}
\hline \multirow{2}{*}{$\begin{array}{c}\text { Waktu } \\
\text { Pengamatan } \\
\text { (HST) }\end{array}$} & \multirow[b]{2}{*}{ Komposisi Pupuk } & \multicolumn{3}{|c|}{ Lama Perendaman (Menit) } & \multirow[b]{2}{*}{ Rerata } \\
\hline & & L1 (30) & L2 (60) & L3 (120) & \\
\hline \multirow{5}{*}{14} & Kontrol (P0) & 4.67 & 4.33 & 4.33 & $4.44^{\mathrm{a}}$ \\
\hline & Tanah + Arang Sekam (P1) & 4.33 & 5.00 & 5.33 & $4.89^{\mathrm{a}}$ \\
\hline & Tanah+ K. Sapi (P2) & 4.00 & 5.00 & 4.67 & $4.56^{\mathrm{a}}$ \\
\hline & Tanah+Sekam+K.Sapi (P3) & 5.00 & 5.00 & 4.67 & $4.89^{\mathrm{a}}$ \\
\hline & Rerata & $4.50^{\mathrm{a}}$ & $4.83^{\mathrm{a}}$ & $4.75^{\mathrm{a}}$ & $(-)$ \\
\hline \multirow{5}{*}{28} & Kontrol (P0) & 6.33 & 6.00 & 6.33 & $6.22^{c}$ \\
\hline & Tanah+Arang Sekam (P1) & 7.00 & 7.00 & 7.33 & $7.11^{\mathrm{b}}$ \\
\hline & Tanah+ K. Sapi (P2) & 7.00 & 7.33 & 7.33 & $7.22^{a b}$ \\
\hline & Tanah+Sekam+K.Sapi (P3) & 7.67 & 8.33 & 7.33 & $7.78^{\mathrm{a}}$ \\
\hline & Rerata & $7.00^{\mathrm{a}}$ & $7.17^{\mathrm{a}}$ & $7.08^{a}$ & $(-)$ \\
\hline \multirow{5}{*}{42} & Kontrol (P0) & 8.33 & 7.33 & 8.33 & $8.00^{c}$ \\
\hline & Tanah+Arang Sekam (P1) & 9.67 & 10.67 & 10.33 & $10.22^{b}$ \\
\hline & Tanah+ K. Sapi (P2) & 10.00 & 10.00 & 11.33 & $10.44^{b}$ \\
\hline & Tanah+Sekam+K.Sapi (P3) & 12.00 & 12.00 & 11.00 & $11.67^{\mathrm{a}}$ \\
\hline & Rerata & $10.00^{\mathrm{a}}$ & $10.00^{\mathrm{a}}$ & $10.25^{\mathrm{a}}$ & $(-)$ \\
\hline \multirow{5}{*}{56} & Kontrol (P0) & 10.00 & 10.00 & 10.33 & $10.11^{\mathrm{d}}$ \\
\hline & Tanah+Arang Sekam (P1) & 13.00 & 13.67 & 12.67 & $13.11^{\mathrm{c}}$ \\
\hline & Tanah+ K. Sapi (P2) & 14.33 & 14.00 & 15.33 & $14.56^{b}$ \\
\hline & Tanah+Sekam+K.Sapi (P3) & 15.33 & 16.00 & 15.33 & $15.56^{\mathrm{a}}$ \\
\hline & Rerata & $13.17^{\mathrm{a}}$ & $13.42^{\mathrm{a}}$ & $13.42^{\mathrm{a}}$ & $(-)$ \\
\hline
\end{tabular}

Keterangan: Angka pada baris dan kolom diikuti huruf yang sama menunjukkan beda pada tingkat nyata 5\% menurut uji DMRT. (-) tidak terjadi interaksi antar faktor

\section{Diameter Batang}

Hasil sidik ragam (anova) menunjukkan bahwa tidak terjadi interaksi antara komposisi pupuk dan lama perendaman terhadap diameter batang tanaman Pepaya. Aras perlakuan lama perendaman tidak terjadi beda nyata antar aras perlakuan sedangkan aras perlakuan media tanam menunjukkan berbeda nyata dari awal pengamatan hingga akhir pengamatan dengan aras perlakuan tanah + arang sekam padi + pupuk kandang sapi menghasilkan diameter batang paling besar (Tabel. 3).

Tabel 3. Diameter Batang

\begin{tabular}{|c|c|c|c|c|c|}
\hline \multirow{2}{*}{$\begin{array}{c}\text { Waktu } \\
\text { Pengamatan } \\
\text { (HST) }\end{array}$} & \multirow[b]{2}{*}{ Komposisi Pupuk } & \multicolumn{3}{|c|}{ Lama Perendaman (Menit) } & \multirow[b]{2}{*}{ Rerata } \\
\hline & & L1 (30) & L2 (60) & L3 (120) & \\
\hline \multirow{5}{*}{14} & Kontrol (P0) & 0.13 & 0.13 & 0.13 & $0.13^{\mathrm{b}}$ \\
\hline & Tanah+Arang Sekam (P1) & 0.20 & 0.20 & 0.20 & $0.20^{\mathrm{a}}$ \\
\hline & Tanah+ K. Sapi (P2) & 0.17 & 0.20 & 0.23 & $0.20^{\mathrm{a}}$ \\
\hline & Tanah+Sekam+K.Sapi (P3) & 0.20 & 0.20 & 0.20 & $0.20^{\mathrm{a}}$ \\
\hline & Rerata & $0.18^{\mathrm{a}}$ & $0.18^{\mathrm{a}}$ & $0.19^{\mathrm{a}}$ & $(-)$ \\
\hline \multirow{5}{*}{28} & Kontrol (P0) & 0.23 & 0.23 & 0.23 & $0.23^{\mathrm{c}}$ \\
\hline & Tanah+Arang Sekam (P1) & 0.30 & 0.30 & 0.30 & $0.30^{\mathrm{b}}$ \\
\hline & Tanah+ K. Sapi (P2) & 0.30 & 0.30 & 0.33 & $0.31^{\mathrm{b}}$ \\
\hline & Tanah+Sekam+K.Sapi (P3) & 0.40 & 0.37 & 0.37 & $0.38^{\mathrm{a}}$ \\
\hline & Rerata & $0.31^{\mathrm{a}}$ & $0.30^{\mathrm{a}}$ & $0.31^{\mathrm{a}}$ & $(-)$ \\
\hline
\end{tabular}

\begin{tabular}{lllllc}
\hline \multirow{4}{*}{42} & Kontrol (P0) & 0.33 & 0.33 & 0.30 & $0.32^{\mathrm{c}}$ \\
Tanah+Arang Sekam (P1) & 0.40 & 0.40 & 0.47 & $0.42^{\mathrm{b}}$ \\
& Tanah+K. Sapi (P2) & 0.47 & 0.50 & 0.53 & $0.50^{\mathrm{a}}$ \\
& Tanah+Sekam+K.Sapi (P3) & 0.57 & 0.60 & 0.50 & $0.56^{\mathrm{a}}$ \\
\cline { 2 - 5 } & Rerata & $0.44^{\mathrm{a}}$ & $0.46^{\mathrm{a}}$ & $0.45^{\mathrm{a}}$ & $(-)$ \\
\hline \multirow{4}{*}{56} & 0.47 & 0.50 & 0.43 & $0.47^{\mathrm{c}}$ \\
& Kontrol (P0) & 0.57 & 0.50 & 0.60 & $0.56^{\mathrm{c}}$ \\
& Tanah+Arang Sekam (P1) & 0.67 & 0.73 & 0.77 & $0.72^{\mathrm{b}}$ \\
& Tanah+ K. Sapi (P2) & 0.73 & $0.86^{\mathrm{a}}$ \\
\cline { 2 - 5 } & Tanah+Sekam+K.Sapi (P3) & 0.93 & 0.90 & 0.73 & $(-)$
\end{tabular}

Keterangan: Angka pada baris dan kolom diikuti huruf yang sama menunjukkan beda pada tingkat nyata $5 \%$ menurut uji DMRT. (-) tidak terjadi interaksi antar faktor

\subsection{Pembahasan}

Pemberian tanah, arang sekam dan pupuk kandang sapi memberikan pertumbuhan yang paling baik pada tanaman Pepaya. Pertumbuhan terbaik ini terlihat dari tanaman yang paling tinggi, diameter terbesar dan jumlah daun yang terbanyak. Dimana parameter-parameter tersebut secara nyata berbeda dengan tanaman yang tidak diberikan tanah + arang sekam, tanah + pupuk kandang sapi dan kontrol. Lama perendaman berpengaruh nyata terhadap sebagian besar parameter yang diukur, dimana lama perendaman 120 menit (2 Jam) memberikan pertumbuhan terbaik yakni tanaman yang paling tinggi, diameter batang terbesar dan jumlah daun terbanyak berbeda nyata dengan perlakuan lama perendaman 30 menit dan 60 menit. Fungsi perendaman secara langsung merupakan teknik invigorasi benih melalui imbibisi air secara terkontrol. Saat ini invigorasi merupakan salah satu alternatif yang dapat digunakan untuk mengatasi mutuh benih kualitas rendah dengan cara melakukan benih sebelum ditanam dengan mengaktifkan kembali metabolisme benih sehingga benih siap memasuki fase perkecambahan. Selain proses invigorasi, proses perendaman mengakibatkan keserempakan perkecambahan serta mengurangi tekanan lingkungan. Keserempakan munculnya radikula akan berpengaruh terhadap keseragaman panjang hipokotil, parameter ini selanjutnya akan menunjukkan keragaan bibit dalam kemampuan mengangkat kotiledon (Heydecker, 1973).

Arang sekam merupakan media tanam yang praktis digunakan karena tidak perlu disterilisasi. Hal ini disebabkan mikroba patogen telah mati selama proses pembakaran. Arang sekam mengandung unsur hara N 0,3\%, $\mathrm{P}_{2} 0_{5} 15 \%$, $\mathrm{K}_{2} \mathrm{O} 31 \%$, arang sekam juga memiliki kemampuan menahan air tinggi, bertesktur remah, siklus udara dan KTK tinggi dan dapat mengabsosbsi sinar matahari dengan efektif (Fahmi, 2013; Soemeinaboedhy dan Tejowulan, 2007). Di dalam tanah arang sekam bekerja dengan cara memperbaiki struktur fisik, kimia dan biologi tanah. Arang sekam dapat meningkatkan porositas tanah sehingga tanah menjadi gembur sekaligus juga meningkatkan kemampuan tanah yang menyerap air.

Arang sekam mempunyai sikap yang mudah mengikat air tidak mudah menggumpal, harganya relatif murah, mempunyai porositas yang baik, ringan, steril dan bahannnya mudah didapat (Prihmantoro, 2003). Keunggulan arang sekam yang dapat mengikat air dan unsur hara akan berdampak positif dalam penggunaannya dengan pupuk kandang karena beberapa jenis unsur hara dalam pupuk kandang yang mudah hilang dapat diikat oleh arang sekam. Dengan demikian pemanfaatan unsur hara oleh akar tanaman menjadi lebih mudah sehingga pertumbuhan dan hasil tanaman meningkat. Pupuk kandang sapi dapat menambah ketersediaan unsur-unsur hara bagi tanaman, juga mengembangkan kehidupan mikroorganisme di dalam tanah. Mikroorganisme berperan mengubah seresah dan sisa-sisa tanaman menjadi humus, senyawa-senyawa tertentu disintesa menjadi bahan-bahan yang berguna bagi tanaman (Lingga, 1991). Pupuk kandang sapi memiliki keunggulan dibanding pupuk kandang yang lain yaitu mempunyai kadar serat yang tinggi seperti selulosa, menyediakan unsur hara makro dan mikro bagi tanaman, serta memperbaiki daya serap air pada tanah (Hartatik dan Widowati, 2010).

\section{Simpulan}

Hasil penelitian ini menunjukkan bahwa tanaman Pepaya yang diberikan perlakuan lama perendaman benih dalam air hangat selama 120 menit dan media tanam tanah + arang sekam + pupuk kandang sapi dapat meningkatkan pertumbuhan awal tanaman pepaya yang dapat diekspresikan dalam bentuk tinggi tanaman tertinggi, jumlah daun terbanyak dan diameter terbesar.

\section{Pustaka}

Barus A. 2008. Agroteknologi Tanaman buah-buahan. Medan USU-Press.

Fahmi, I. Z. 2013. Media tanam hidroponik dari arang sekam. Balai Besar Perbenihan Dan Proteksi Tanaman Perkebunan. Surabaya.

Gomez K A dan Gomez A A. 2010. Prosedur statistic untuk penelitian. Edisi ke 2. Jakarta: UI Press.

Hartatik, W. dan L. R. Widowati. 2010. Pupuk kandang.http://www. balitanah. litbang. deptan. go.id

Heydecker,W.J. Higgins, dan R. L. Gulliver.1973. Accelerated Germinartin By Osmotic Seed Treatment. Natue 246: 42-46G

Isro'i. 2008. Balai Penelitian Bioteknologi Perkebunan Indonesia, Bogor.

Lingga, P. 1991. Jenis dan kandungan hara pada beberapa kotoran Ternak. Pusat pelatihan pertanian dan pedesaan swadaya (P4S) ANTANAN Bogor. 
Lisarini Endah, \& Suwandi. 2011, Pengaruh Media Perendaman Terhadap Pematahan Dormansi, Perkecambahan Dan Vigositas Bibit Pepaya (Carica papaya L.). Journal Of Agroscience, Vol. 2.

Mayadewi, Ari. (2007). Jenis Pupuk Kandang dan jarak tanam terhadap pertumbuhan gulma hasil Jagung Manis. Agritrop,26 (4):153-159 ISN: 02158620.

Nasahi, C. 2010. Peran Mikroba Dalam Pertanian Organik Jurusan Hama dan Penyakit Tumbuhan. Fakultas Pertanian. Bandung Universitas Padjadjaran.

Nurngaini, Maryana dan R. Febriyanto. 2017. Viabilitas Benih Pepaya (carica papaya) dari Bagian Buah yang Berbeda dengan Perendaman air Daya Pertanian, Perkebunan dan Peternakan dalam Mendukung Ketahanan Pangan Nasional" dalam Rangka Dies Natalis UNS ke 41, 30 Maret 2017, Surakarta.

Prihmantoro, H. 2003. Memupuk tanaman sayur. Penebar swadaya. Jakarta.

Sutedjo, M.M. 1987. Pupuk dan Cara Pemupukuan. Jakarta. Rineka Cipta.

Sankat, C.K. And R. Maharaj. 1997. Pepaya. p.169-189.In S. K, Mitra (Ed) Postharvest Phisiology and Storage of tropikal and Suptropical Fruits. USA Cab. Internasional.

Soemeinaboedhy, N. dan R. S. Tejowulan. 2007. Pemanfaatan beberapa macam arang sebagai sumber unsur hara $\mathrm{P}$ dan $\mathrm{K}$ serta sebagai pembenah tanah. Jurusan ilmu tanah Fakultas Pertanian Universitas Mataram. Agroteksos. 17 (2): $114-112$. 